\title{
Fermentation quality of lucerne laboratory silage treated with Clostridium cellobioparum, formic acid and Lactomix
}

\author{
A. Baranowski ${ }^{1}$ and S. Russel ${ }^{2}$ \\ ${ }^{\prime}$ Institute of Genetics and Animal Breeding, Polish Academy of Sciences \\ Jastrzebiec, 05-55I Mroków, Poland \\ ${ }^{2}$ Agricultural University of Warsaw \\ Rakowiecka 26/28, 02-525 Warszawa, Poland
}

(Received 27 October 1993; accepted 21 February 1994)

\begin{abstract}
The experiment was designed to compare and evaluate the effect of the addition of C. cellobioparum bacteria, or other standard additives, to lucerne silage noting the resulting quality. The first cut of direct-cut lucerne was ensiled in laboratory scale and treated as follows: I. untreated (control), II. formic acid (FA) $80 \%-2 \mathrm{ml} \mathrm{kg}^{-1}$. III. Clostridium cellobioparum live cellulolytic bacteria culture added in a water suspension at the rate of $10 \mathrm{ml} \mathrm{kg}(\mathrm{Cclb})-1 \mathrm{x} 10^{6} \mathrm{~g}^{-1}$, IV. Clostridium cellobioparum bacteria culture $-1 \times 10^{6} \mathrm{~g}^{-1}$ live cellulolytic bacterial culture added in a water suspension at the rate of $10 \mathrm{ml} / \mathrm{kg}(\mathrm{Cclb})$ and Lactomix (LAC) $-1.5 \mathrm{~g} \mathrm{~kg}^{-1}, \mathrm{~V}$. Lactomix $-1.5 \mathrm{~g} \mathrm{~kg}^{-1}$.

Following an eight-week storage time the results were analyzed. FA treated silage was well preserved, with a $\mathrm{pH}$ of 4.10 and protein degradation rate of $75.4 \mathrm{~g}$ ammonia $\mathrm{N} \mathrm{kg}^{-1}$ total $\mathrm{N}$. The fermentation parameters of the Cclb inoculated silage were within an acceptable range, with a $\mathrm{pH}$ of 4.17 and degradation rate of $102.6 \mathrm{~g}$ ammonia $\mathrm{N} \mathrm{kg}^{-1}$ total $\mathrm{N}$. The ammonia levels of LAC inoculated silage were found to be $119.5 \mathrm{~g}_{\text {ammonia }} \mathrm{N} \mathrm{kg}^{-1}$ total $\mathrm{N}$. Hence, the Cclb was found to have better fermentation quality than the LAC-inoculated samples, but slightly lower than the FA treatment.
\end{abstract}

KEY WORDS: lucerne silage, additives

\section{INTRODUCTION}

Previous experiments (Baranowski and Russel, 1993) indicate that inoculation of direct-cut meadow grass with cellulolytic bacteria culture Clostridium cellobioparum decreases fibre fraction content in silage when compared to untreated silage. The reduction in neutral detergent fibre (NDF) and acid detergent fibre (ADF) content, along with higher amounts of fermentation acids, is thought to occur due to the bacterial degradation of cell wall components and hence promotes the availability of a more fermentable substrates. The present 
experiment was designed to evaluate the effect of adding C. cellobioparum culture on silage fermentation in relation to other additives.

\section{MATERIAL AND METHODS}

The silages were obtained from the first cut of lucerne (Medicago sativa L.), harvested on 24 June (flowering), and chopped into $1 \mathrm{~cm}$ long chaffs. Three samples of original forage $(n=3)$ were taken before treating and ensiling, for chemical analysis.

The direct-cut lucerne was ensiled on a laboratory scale ( 11 Weck jars; ca $750 \mathrm{~g}$ fresh forage). Treatments were as follows:

I. untreated (control),

II. formic acid (FA) $80 \%-2 \mathrm{ml} \mathrm{kg}{ }^{-1}$,

III. Clostridium cellobioparum live cellulolytic bacteria culture added in a water suspension at the rate of $10 \mathrm{ml} / \mathrm{kg}(\mathrm{Cclb})-1 \times 10^{6} \mathrm{~g}^{-1}$,

IV. Clostridium cellobioparum bacteria culture $-1 \times 10^{6} \mathrm{~g}^{-1}$ live cellulolytic bacteria culture added in a water suspension at the rate of $10 \mathrm{ml} \mathrm{kg}(\mathrm{Cclb})$ and Lactomix (LAC) - $1.5 \mathrm{~g} \mathrm{~kg}^{-1}$,

V. Lactomix $-1.5 \mathrm{~g} \mathrm{~kg}^{-1}$.

Each treatment was ensiled in 4 weighed jars, constituting four replicates (except treatment $\mathrm{V} ; \mathrm{n}=3$ ). The jars were stored for eight weeks in the dark at room temperature and were weighed at seven-day intervals to determine gas losses during fermentation (Berg, 1971). Silages obtained were rapidly frozen at $-20^{\circ} \mathrm{C}$ until chemical anlysis.

The proximate analysis of orginal forage and silages was conducted according to standard methods (Skulmowski, 1974). Determination of NDF, ADF, and acid detergent lignin (ADL) were made according to Tecator Application Notes (Tecator, Sweden) No. 06/78, 03/78 and 04/78, respectively. Dry matter (DM) content of silage was corrected according to Berg and Weissbach (1976). pH value, organic acids, alcohol, and ammonia contents were determined using Polish Standards (Norma Branżowa, 1974).

The differences among treatments were examined by analysis of variance. The means were compared by the Duncan test and the significance was established at $\mathbf{P} \leqslant 0.05$ and $\mathbf{P} \leqslant 0.01$.

\section{RESULTS}

All of the used additives had a marked effect on gas losses during fermentation (Fig. 1). As could be expected, the untreated silage (I) showed the highest gas losses, which at the and of storage time reached $9.4 \%$ of loaded DM. The lowest gas losses were noticed in silage II, treated with FA (1.9\% of DM) and silage III, 


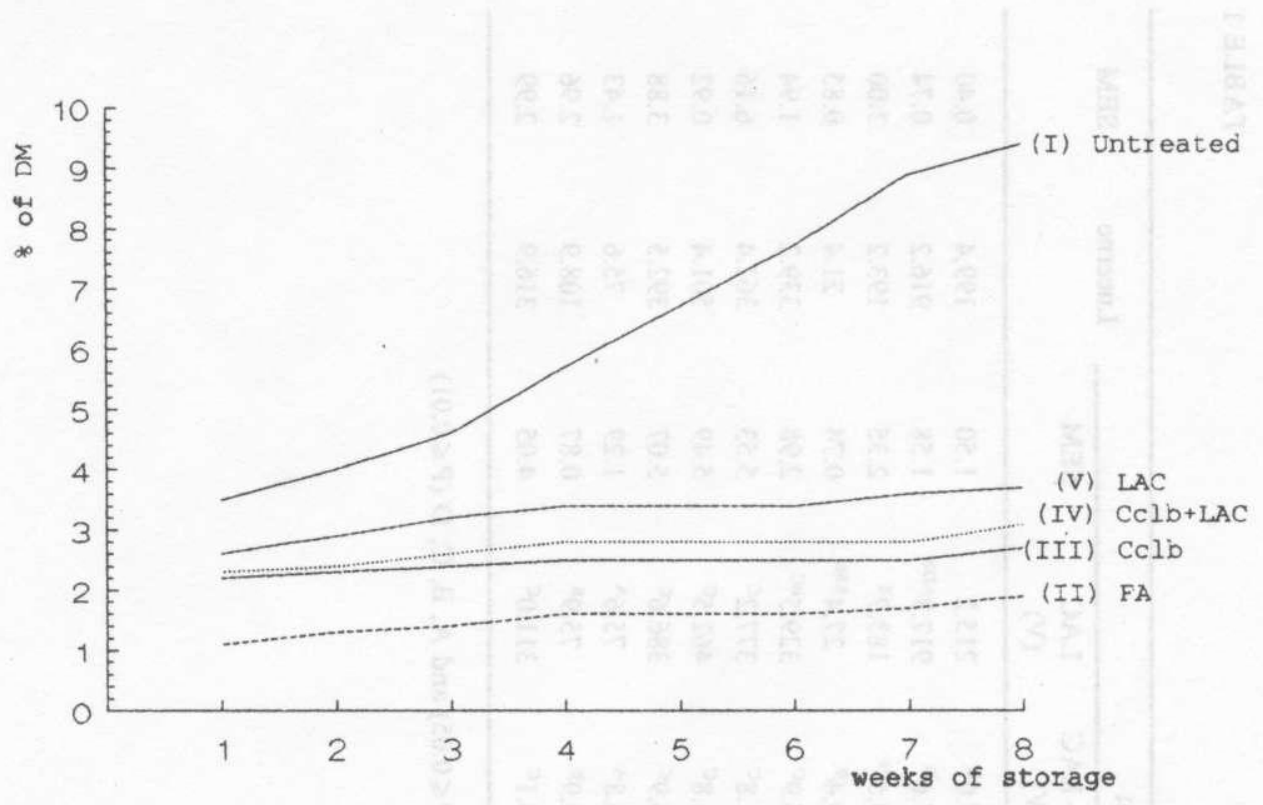

Fig. 1. Gas losses during fermentation of silages (in \% of loaded lucerne DM)

inoculated with C. cellobioparum (2.7\% of DM). Lactic acid bacterial inoculant used alone (V) or together with C. cellobioparum (IV) had no effect on the reduction of gas losses ( 3.7 and $3.1 \%$ of DM, respectively) as compared with FA - treated (II) and Cclb-inoculated (III) silages.

The chemical composition of silages and fresh lucerne are given in Table 1. The silages obtained, with additives, were characterized by higher DM content $(\mathrm{P} \leqslant 0.01)$ relative to the untreated silage. The differences in the DM content observed among LAC inoculated silage and other treated silages can be partly explained by the different amount of physical nature of the additives used for ensiling lucerne. Marginal differences were observed in the content of crude protein $(\mathrm{CP})$ among $\mathrm{Cclb}$ or LAC-inculated silages and FA-treated silage. However, the untreated silage had a higher $\mathrm{CP}$ content than additive-containing silages. The content of NDF and ADF fractions in the untreated silage was significantly higher $(\mathrm{P} \leqslant 0.01)$ as compared with all treated silages. The $\mathrm{Cclb}$ inoculated silage showed a lower NDF and ADF content than LAC or Cclb with LAC inoculated silages, but the differences were not significant.

The results, shown in Table 2, indicate that additives improved the fermentation parameters of all treated silages in comparison with untreated silage. The $\mathrm{pH}$ values of FA treated silage (4.10) and Cclb inoculated silage (4.17) were lower 
TABLE 1

Composition of lucerne and silages, $\mathrm{g} \mathrm{kg}^{-1}$ dry matter

SEM

\begin{tabular}{|c|c|c|c|c|c|c|c|}
\hline \multicolumn{6}{|c|}{ Sila } & \multirow{2}{*}{ Lucerne } & \multirow{2}{*}{ SEM } \\
\hline $\begin{array}{l}\text { Untreated } \\
\text { (II) }\end{array}$ & $\begin{array}{l}\text { FA } \\
\text { (II) }\end{array}$ & $\begin{array}{l}\text { Cclb } \\
\text { (III) }\end{array}$ & $\begin{array}{c}\mathrm{Cclb}+\mathrm{LAC} \\
\text { (IV) }\end{array}$ & $\begin{array}{l}\text { LAC } \\
\text { (V) }\end{array}$ & SEM & & \\
\hline $196.3^{\mathrm{A}}$ & $208.3^{8 u}$ & $203.3^{\mathrm{Bb}}$ & $207.0^{\mathrm{B}}$ & 215.2 & 1.50 & 199,4 & 0.40 \\
\hline $914.9^{A_{4}}$ & $933.2^{\mathrm{B}}$ & $923.0^{C}$ & $917.6^{\mathrm{D}}$ & $917.8^{\wedge \mathrm{Db}}$ & 1.58 & 916.2 & 0.74 \\
\hline $206.6^{\wedge}$ & $185.0^{\mathrm{B}}$ & $187.5^{\mathrm{Ba}}$ & $180.5^{\mathrm{Bh}}$ & $183.7^{\mathrm{B}}$ & 2.35 & 193.2 & 3.00 \\
\hline $22.9^{\mathrm{Aa}}$ & $29.0^{\mathrm{B}}$ & $30.1^{\mathrm{B}}$ & $29.4^{\mathrm{B}}$ & $27.4^{\mathrm{ABb}}$ & 0.74 & 21.4 & 0.85 \\
\hline $357.7^{\mathrm{A}}$ & $324.4^{\mathrm{B}}$ & $329.1^{\mathrm{BC}}$ & $335.9^{\mathrm{C}}$ & $329.5^{\mathrm{BC}}$ & 2.98 & 339.2 & 1.94 \\
\hline $327.7^{\mathrm{A}}$ & $394.8^{B}$ & $376.3^{c}$ & $371.8^{\mathrm{c}}$ & $377.2^{c}$ & 5.53 & 362.4 & 6.16 \\
\hline $482.7^{\mathrm{A}}$ & $415.3^{\mathrm{B}}$ & $452.7^{\complement}$ & $458.8^{\circ}$ & $462.5^{\mathrm{C}}$ & 5.49 & 501.4 & 0.92 \\
\hline $409.6^{\wedge}$ & $346.7^{\mathrm{B}}$ & $384.6^{\circ}$ & $384.9^{\circ}$ & $386.6^{\circ}$ & 5.07 & 392.5 & 3.88 \\
\hline $75.8^{\mathrm{A}}$ & $63.2^{\mathrm{B}}$ & $75.8^{\wedge}$ & $74.8^{\wedge}$ & $75.6^{A}$ & 1.29 & 75.6 & 1.43 \\
\hline $73.1^{\mathrm{d}}$ & $68.6^{\mathrm{Ab}}$ & $68.1^{A b c}$ & $73.9^{\mathrm{B}}$ & $75.9^{\mathrm{B}}$ & 0.87 & 108.9 & 2.96 \\
\hline $333.8^{\mathrm{A}}$ & $283.5^{\mathrm{B}}$ & $308.8^{C}$ & $310.1^{\mathrm{C}}$ & $311.0^{\mathrm{C}}$ & 4.05 & 316.9 & 2.99 \\
\hline
\end{tabular}

means in the same line with different letters are significantly different: $a, b, c(P \leqslant 0.05)$ and $A, B, C, D(P \leqslant 0.01)$ 
TABLE 2

$\mathrm{U}$ - undetected

means in the same line with different letters are significantly different: $a, b, c(P \leqslant 0.05)$ and $A, B, C, D,(P \leqslant 0.01)$ 
than of the remaining samples. Addition of LAC inoculant alone or together with $\mathrm{Cclb}$ significantly decreased $(\mathrm{P} \leqslant 0.01)$ the $\mathrm{pH}$ of experimental silages $(4.36$ and 4.26 respectively) relative to the untreated one (5.67).

The untreated silage contained less lactic acid $(P \leqslant 0.01)$ than remaining silages. Differences in lactic acid content between FA-treated and LAC or Cclb with LAC inoculated silages $(80.9,85.0$, and $82.6 \mathrm{~g} / \mathrm{kg} \mathrm{DM}$, respectively) were not significant. In contrast, the $\mathrm{Cclb}$ inoculated silage showed a significantly $(P \leqslant 0.05$ or $P \leqslant 0.01)$ higher lactic acid content $(103.4 \mathrm{~g} / \mathrm{kg} D M)$ than other additive groups. The $\mathrm{Cclb}$ inoculated silage had also the lowest acetic acid content $(44.8 \mathrm{~g} / \mathrm{kg} \mathrm{DM})$ as compared with LAC inoculated silage $(60.5 \mathrm{~g} / \mathrm{kg} \mathrm{DM}$; $P \leqslant 0.05)$ or Cclb with LAC $(77.5 \mathrm{~g} / \mathrm{kg}$ DM $P \leqslant 0.01)$. The higher lactic-acetic acid ratio in $\mathrm{Cclb}$ inoculated silage than in remaining samples suggests that the use of Clostridium cellobioparum leads to a more homolactic fermentation of silage.

The proportion of ammonia- $\mathrm{N}$ in total $\mathrm{N}$ was significantly higher $(\mathrm{P} \leqslant 0.01)$ in untreated silage $(145.3 \mathrm{~g} / \mathrm{kg})$ as compared to the rest. The LAC inoculated used alone or together with $\mathrm{Cclb}$ did not reduce the proportion of ammonia-N in total $\mathrm{N}$ in either silages (119.5 and $111.2 \mathrm{~g} / \mathrm{kg}$, respectively) as compared with Cclb-inoculated $(102.6 \mathrm{~g} / \mathrm{kg})$ and FA treated $(75.4 \mathrm{~g} / \mathrm{kg})$ samples.

\section{DISCUSSION}

As was also shown in previous experiments on grass silage (Baranowski and Russel, 1993), Clostridium cellobioparum bacterial additive decreased ( $\mathrm{P} \leqslant 0.01)$ the NDF and ADF contents in direct-cut lucerne silage compared to the untreated sample. The observed lowest content of fibre fractions in FA treated silage may reflect a relatively strong effect of formic acid on the cell wall components (Morrison, 1979; Jaakkola et al., 1991) The positive effect of formic acid on preservation is commonly known and was here confirmed. The FA treated silage was well preserved, as evidenced by the low $\mathrm{pH}(4.10)$ and low protein degradation rate $\left(75.4 \mathrm{~g}\right.$ ammonia- $\mathrm{N} \mathrm{kg}^{-1}$ total $\left.\mathrm{N}\right)$.

The addition of commercial lactic acid inoculant (LAC) improved ensiling conditions of fresh lucerne, but fermentation characteristics of the obtained silage were not satisfactory as compared with FA treated and $\mathrm{Cclb}$ inoculated silages. The fermentation parameters of Cclb with LAC-inoculated silage $(\mathrm{Cclb}+\mathrm{LAC})$ were midway between the two tested individually.

In comparison with lactic acid inoculant, and mixed inoculant, the use of $C$. cellobioparum bacteria inhibited acetic fermentation, supported lactic fermentation, and restricted proteolysis in the silage to the level characteristic for well preserved lucerne laboratory silages (Voss, 1967). 
The fermentation using Cclb was accompanied by low gas losses, and was found to be in the range of values given by Rahn (1992) for butyric-free clover and lucerne silages.

Overall, the fermentation parameters of $\mathrm{Cclb}$ inoculated silage were acceptable becouse of the low $\mathrm{pH}$ (4.17), high amount of lactic acid ( $103.4 \mathrm{~g} / \mathrm{kg} \mathrm{DM})$, and the proportion of ammonia $\left(102.6 \mathrm{~g} \mathrm{~kg}^{-1}\right.$ total $\mathrm{N}$ ), which was higher compared with FA treated silage, but significantly lower $(P \leqslant 0.01)$ in relation to LACinoculated silage $\left(119.5 \mathrm{~g} \mathrm{~kg}^{-1}\right.$ total $\left.\mathrm{N}\right)$. The fermentation quality of $C$. cellobioparum - inoculated silage was better than that of LAC-inoculated silage and slightly lower than FA-treated silage.

\section{REFERENCES}

Baranowski A., Russel S., 1993. Quality of meadow grass silage inoculated with cellulolytic bacteria. J. Anim. Feed Sci. 2, 59-65

Berg K., 1971. Die Trockensubstanzbestimmung von Silagen und die Erfassung flüchtiger den Futterwert beeinflussender Verbindungen sowie Modellversuche zur Ermittlung des Gärverlustes. Dissertation. Universität Rostock

Berg K., Weissbach F., 1976. Untersuchungen zur vollständigen Erfassung des Trockensubstanzgehaltes von Silagen. 1. Mitteilung. Ermittlung der Stoffverluste bei der Trocknung von Silageproben. Arch. Tierernähr. 26, 661-672

Jaakkola S., Huhtanen P., Hissa K., 1991. The effect of cell wall degrading enzymes or formic acid on fermentation quality and on digestion of grass silage by cattle. Grass Forage Sci. 46, 75-87

Morrison I.M., 1979. Changes in the cell wall components of laboratory silages and the effect of various additives on these changes. J. Agric. Sci., Camb. 93, 581-586

Norma Branżowa, 1974. Pasze. Metody oceny jakości i wartości pokarmowej kiszonek. BN-74/9162-01

Rahn S., 1992. Untersuchungen zum Einfluss chemischer Siliermittel auf den Gärungsverlauf, die Gärverluste und die aerobe Stabilität von Grünfuttersilagen. Dissertation. Humboldt-Universität zu Berlin

Skulmowski J., 1974. Metody określania składu pasz i ich jakości. PWRiL, Warszawa

Voss N., 1967. Untersuchungen über den Proteinabbau in Gras-und Luzernesilage. Wirt. Futter 13, $130-145$ 


\section{STRESZCZENIE}

Jakość kiszonek z lucerny sporządzonych z dodatkiem Clostridium cellobioparum, kwasu mrówkowego i Lactomixu

Pierwszy pokos lucerny $(19,94 \%$ s.m.) zakiszano w słojach Wecka (ok. $750 \mathrm{~g}$ świeżej masy) bez dodatków (I) lub z dodatkami: kwasu mrówkowego $-2 \mathrm{ml} \mathrm{kg}^{-1}$ (II), cellulolitycznych bakterii Clostridium cellobioparum $-1 \times 10^{6} \mathrm{~g}^{-1}$ (III), Clostridium cellobioparum $-1 \times 10^{6} \mathrm{~g}^{-1}$ i Laktomixu $-1,5$ $\mathrm{g} \mathrm{kg}^{-1}$ (IV) oraz Laktomixu - $1,5 \mathrm{~g} \mathrm{~kg}^{-1}$ (V).

Po 8-tygodniowym okresie fermentacji $\mathrm{pH}$, zawartość kwasu mlekowego ( $\mathrm{g} \mathrm{kg}^{-1} \mathrm{~s}$.m.) i amoniaku ( $\mathrm{g} \mathrm{kg}^{-1}$ s.m.) oraz udział N-NH $\mathrm{N}_{3}$ w N całkowitym $\left(\mathrm{g} \mathrm{kg}^{-1}\right)$ badanych kiszonek wynosiły odpowiednio: (I) $-5,67 ; 28,5 ; 5,9$ i 145,3; (II) - 4,10; 80,9; 2,7 i 75,4; (III) - 4,17; 103,4; 3,7 i 102,6; (IV) - 4,26; 82,6; 3,9 i 111,$2 ;(\mathrm{V})-4,36 ; 85,0 ; 4,3$ i 119,5 .

Dodatek bakterii Clostridium cellobioparum korzystniej wpłynął na przebieg procesów fermentacyjnych w zakiszonej lucernie niż Lactomixu. Stąd kiszonka sporządzona z dodatkiem bakterii była lepszej jakości niż z dodatkiem Lactomixu, lecz nieznacznie gorsza niż kiszonka z dodatkiem kwasu mrówkowego. 